\title{
Mediators of Reading Motivation Among Filipino Collegiate Students
}

\author{
Marie Grace C. Reoperez* \\ College of Education, University of the Philippines \\ Corresponding author: Marie Grace C. Reoperez, E-mail: mcreoperez@up.edu.ph
}

\section{ARTICLE INFO}

Article history

Received: October 3, 2018

Accepted: January 27, 2019

Published: January 31, 2019

Volume: 7 Issue: 1

Conflicts of interest: None

Funding: None

\begin{abstract}
In literacy development, the affective conditions are equally important as the cognitive conditions. However, the role of motivation, an essential affective component of the reading process and what drives it are often overlooked specially among adolescent readers. Using an ethnographic approach, this paper identifies mediators of reading motivation among collegiate learners through analyses of online journals, reading profiles, and transcribed interviews of 17 Filipino collegiate students. The study draws largely from the reading model of Guthrie and Wigfield (2000) and Kozulin's (2003) discussion of mediated learning based on Vygotsky's (1978) sociocultural theory. Results showed that psychological and emotional satisfaction, prosocial goals, prevailing social values, and multi-modal learning experiences were the prime drivers of motivation to read among adolescent readers. The findings of this study underscore the importance of understanding and knowing what teenagers read, why they read, and what engages them to read. Such knowledge will inform instructional decisions on selection of learning resources and literacy activities that are engaging and relevant to adolescent learners' experiences, needs, and goals.
\end{abstract}

Key words: Adolescent Literacy, Reading Motivation, Collegiate Readers, Literacy Development

\section{INTRODUCTION}

Motivation, an essential affective element in reading is a driving force in academic achievement (Brozo, Sulkunen, Shiel, Garbe, Pandian, Valtin, 2014; Guthrie \& Wigfield, 2000; Kim, 2011; Lau, 2009; Martin, 2009). Highly motivated readers can transcend difficulty of materials and adversities in life brought about by poverty (OECD, 2010). They read beyond what is required in the class and mostly for the sheer enjoyment that they derive from the act. Since they read more, they become more strategic in bridging comprehension gaps (Gilbert \& Fister, 2011). More importantly they can extend their understanding of the texts from literal to critical level. Eventually, these learners get to possess a more integrated understanding of themselves and become more empathetic with fellow human beings (Gilbert \& Fister, 2011; Rosenblatt, 2005).

Unfortunately, despite being a consistent predictor of academic achievement across grade levels, reading motivation is never considered as a important topic in literacy as reflected in the recent annual surveys of the International Literacy Association (ILA, 2017, 2018) on the hottest and most important literacy issues. Furthermore, it is often overlooked in adolescent literacy instruction especially in the tertiary level. What activates motivation among collegiate readers is a less explored area. Studies on reading habits of collegiate students (Gilbert \& Fister, 2011; Huang, Capps, Blacklock, \& Garza,
2014; Lone, 2011) focus more on what they read and the number of hours they spend on reading in and out of school.

In this age of Information and Communication Technologies (ICTs) where the Internet has become an essential part of young people's lives, it is hard to believe that millennial learners are averse to reading. In fact, adolescents spend so much time reading blogs, emails, and other online sources e.g., news, articles, and e-books (Berg, 2011; Conradi, Jang, Craft, Bryant, \& McKenna, 2013; Gilbert \& Fister, 2011). Yet, it is ironic that lack of motivation to read and low engagement in academic reading remain to be a perennial concern among collegiate students as reported in several studies (Brown, Danvers, \& Doran, 2016; Kerr \& Frese, 2017; Kirchoff, 2013; Trice \& Wilmes, 2011). Park and Kim (2016) likewise observe that 'adverse reading behaviors such as displeasure and boredom' (p. 197) are demonstrated when reading academic materials. This indicates that academic reading is not considered as an enjoyable activity by many collegiate students.

To be able to provide teachers a deeper grasp of the nature of motivation among adolescent readers, this study examines, describes, and historicizes collegiate students' reading experiences, preferences, and goals. It is hoped that knowing and understanding what and why adolescents read and what mediates their motivation to read will be helpful in crafting and planning a relevant, engaging, and meaningful literacy instruction. 


\section{LITERATURE REVIEW}

\section{Reading Motivation of Adolescent Learners}

Adolescent readers bring with them cognitive and affective conditions in reading accumulated in the initial stages of education at home and at school (IRA, 2013). Among the affective conditions, researchers agree on the centrality of motivation in adolescents' engagement, attitude toward reading, and achievement (Conradi et al., 2013; Guthrie \& Wigfield, 2000; Judge, 2011; Kim, 2011; NEA, 2007; Reoperez, 2016).

The reading to learn stage which characterizes adolescent literacy is very crucial in terms of the amount and quality of motivation that students bring in the reading act. It is the stage where they will be needing advanced literacy skills to be able to cope with the challenges of content reading which is the thrust of the tertiary level curriculum. However, it is observed that upon reaching the reading to learn stage, interest in reading diminishes (Corpus, McClintic, \& Gayenga, 2009; Guthrie \& Wigfield, 2000; NEA, 2007). The shift from developmental to content reading is seen as the major culprit of the motivational decline. From the familiar story grammar of the narrative texts that they read and enjoy in the early grades, students suddenly find themselves extracting information from expository texts. Oftentimes, the lack of necessary skills to interrogate the different content area materials makes reading difficult and less engaging (NIL, 2007). On the other hand, Lau (2016) argued that motivational change can be attributed to several factors, not just in the shift of curriculum focus. One of these is the impact created by the learning environment. When students are provided with cognitively and emotionally satisfying reading tasks and literacy activities that are reflective of their values and interests (Groenke, 2017), they can be consistently and intrinsically motivated to read. The opposite leads to diminished interest or even refusal to read (Strommen \& Mates, 2004). Additionally, Moyer (2011) suspected that adolescents' literacy activities which are generally taking place online might have been misconstrued as not 'real' reading not only by teachers but by the students themselves. Most likely, these literacy activities do not conform with the traditional view of reading as print-based. Moreover, motivation to read could be adversely affected by the mismatch between what adolescents want to read and what the schools want them to read (Bozack \& Salvaggio, 2013). The differences in the stance that teachers and students adopt when reading likewise contribute to disengagement in reading. Teenagers' growing sense of independence in their choices of reading materials (Green, Walker, Hoover-Dempsey, \& Sandler, 2007; Klauda \& Wigfield, 2012) oftentimes does not factor in the selection of texts and materials. Similarly, when literacy instruction pays too much attention on acquiring information rather than on the 'living through' experiences, no real engagement takes place (Rosenblatt, 2005). And as a consequence reading becomes a boring and dragging activity intended mainly to fulfill academic requirements.

\section{Guthrie and Wigfield's Motivation Theory}

Guthrie and Wigfield's motivation theory (2000) posited that motivation is a complex construct with many facets and components. Goals, self-efficacy, autonomy support, real word interactions, texts, instructional processes, and social motivation drive engagement and motivation in an interrelated manner (Brozo, Shiel, \& Topping, 2007; Pitcher, Albright, DeLaney, Walker, Seunarinesingh, Headley, Mogge, Ridgeway, 2007; Ruddell \& Unrau, 2013). Furthermore, the forces that shape and affect students' reading motivation and engagement are different for age group and populations. For adolescent readers, influential factors include a) peers and family; b) values held about reading; c) reading opportunities at home and at school; and d) sociocultural values (Conradi et al., 2013;; Guthrie \& Cuddington, 2009; Henk, Marinak, \& Melnick, 2012; Klauda, 2009; Klauda \& Wigfield, 2012). Lately, the Internet also figures prominently in adolescents' reading habits and literacy practices (Amicucci, 2014; Moyer, 2011). Research data show that online literacy activities could engage collegiate learners in extended and exploratory reading and writing (Reoperez, 2016) and inspire high school students to be creative and collaborative in their written responses (Johnson, 2010).

Motivation itself mediates the Matthew effect in reading. Increased motivation results in increased engagement and comprehension which in turn results in improved performance and learning (Klauda \& Guthrie, 2014; Logan, Medford, \& Hughes, 2011). Bozack and Salvaggio (2013) demonstrated this in their study where gains in achievement were compared in adolescent boys with varying degree of motivation. Greater gains were recorded for the boys who are highly motivated. In contrast, the boys who were less motivated to read obtained lesser gains in reading achievement. In the same study, it was suggested that motivation may be a predictor of academic success among upper high school students.

\section{Mediated Motivation}

This paper posits that motivation and engagement to read among adolescents are mediated specifically by adults around them as well as by symbols and tools such as books and the Internet. In his sociocultural theory, Vygotsky (1978) views learning as a result of mediation, not of acquisition where children are reduced to being passive recipients of information. For Vygotsky, it is difficult to imagine learning taking place without a sociocultural context. Therefore, the presence of mediating agents is inevitable and at the same time crucial in scaffolding children's learning growth and development (Gredler, 2009).

Kozulin (2003) identified two types of mediation - human and symbolic. Human mediation through feedback, support, and modelling provided by teachers, parents, and other adults is responsible for enhancing the child's performance while symbolic mediation can introduce changes in performance of the child (Kozulin, 2003). Without expanding Vygotsky's theory, performance is replaced with reading motivation in this study. Expansion is no longer necessary since the sociocultural theory already includes the affective aspect of learning as reflected in the behavioral mastery (Levykh, 2008). 


\section{Human and symbolic mediators}

In Vygotsky's model (Kozulin, 2003), learning begins through human mediation which may come in different forms such as encouragement, challenges, feedback, or even the mere presence of an adult. Rogoff (1995) identified three aspects of human mediation: apprenticeship, guided participation, and appropriation. The first pertains to the modeling of the activity; the second to the interaction with people; and the last one to the changes in the individual. On the other hand, SYMBOLIC MEDIATORS pertain to signs, symbols, writing, reading, graphic organizers, and even the Internet which help shape learning experiences and motivation of children. One caveat though, symbolic mediators, according to Kozulin (2003), would only be meaningful if their use is facilitated by a human being who would at the same time communicate to the students the meaning and values of the symbols. As earlier mentioned, there were very few studies that explore how motivation is mediated.

In separate investigations, Schaffner, Schiefele, Ulferts (2013); Klauda and Wigfield (2012); and Wolters, Barnes, Kulesz. York, and Francis (2017) expound on the mediating effects of both human and symbolic tools. By analyzing how intrinsic and extrinsic motivation affect comprehension of Grade 5 students, Schaffner et al. (2013) found out that the amount spent on reading mediates the effects of both kinds of motivation on comprehension. Klauda and Wigfield's study (2012) of fourth and fifth graders which examined the connections between perceived parent and friend support showed that both influenced reading motivation with perceived friend support impacting reading habits. Finally, Wolters et al. (2017) discovered that giving brief oral feedback prior to test taking could increase perceived control. The same study concluded that focus on mastery goals could lead to increased motivation in performing reading tasks. These studies showed the importance of both mediation and mediating agents in reading motivation. The motivation to read is strengthened when mediated by symbolic tools such as time, goals, support, and oral feedback which are all made possible and meaningful through human mediation.

\section{METHOD}

\section{Research Design}

This study which employed the qualitative design made use of ethnography in approaching the mediators of reading motivation of the participants. Reading goals, experiences, and preferences were examined, described, and historicized using online journals, reading profiles, and informal interviews.

\section{Participants}

The participants in this study were 17 students consisting of 5 males and 12 females who were taking up varied college courses. They were enrolled in a literature class in a non-sectarian university in Manila, the capital city of the Philippines and where Filipino and English are the dominant literacies. Being the center of economy and education, students from different parts of the country and from different socio-economic status flock to Manila to study in the collegiate level. The 17 students were identified using purposive sampling. They were chosen because they a) online journals selected for this study; b) were representatives of different courses, socio-economic status, and sexes; and c) belonged to different year levels.

\section{Instrumentation and Procedure}

Data were collected from online journal entries and reading profiles which were both course requirements. Informal interviews which provided additional information on the participants' reading experiences, preferences, and goals were conducted during class sessions. The oral sharings were recorded for analysis and field notes were taken for all class sessions during the entire semester. Being the teacher, I became a participant-observer which made it easier for me to engage the participants in informal interviews and casual conversations outside of our classes.

For the reading profile, a simplified version of the Motivation to Read Profile (MRP): Conversational Interview of Gambrell, Palmer, and Mazzoni (1996) was provided to the participants at the beginning of the semester. While the original MRP has three parts which emphasized three types of reading namely narrative, informational, and general reading, the adapted one has two parts only. Part one instructs the participants to describe themselves and share something about their dreams, aspirations, likes, and dislikes. The second part consists of ten questions selected from each part of MRP. The questions elicit information on the following: a) most interesting story they have read; b) important thing they have learned recently from a reading material; c) a book that they are currently reading; $d$ ) their favorite authors; e) a book that they would like to read in the future; f) things that bring excitement to read; and g) influences of their reading experiences on them. On the other hand, entries from their online journals discussed their reading experiences as young children and as growing up adolescents; their goals and purposes in reading; and their reading preferences. Separate Wordpress sites were created for the online journal writing and reading profile activity. The participants posted their responses for both through the comment sections of the sites. Responses for both activities were shared and discussed in class. The transcribed interviews, journal entries, and information elicited from the reading profiles were interpreted and analyzed using thematic analysis. Themes and patterns were identified and categorized.

\section{RESULTS AND DISCUSSION}

\section{Reading Beyond the Classroom}

Journal entries revealed that the participants engaged in non-academic reading for a variety of reasons other than getting information. Some read to feel good as reflected in these entries (for ethical purposes, pseudonyms were used):

I always read every time I feel bad and I feel to give up (sic). (Maits)

It really helps me feel confident, it gives me strength. (Camille)

When I am down, I would find myself buying a book which would make me feel less-burdened. (Neneng) 
Some wanted to experience new worlds and a gamut of emotions:

To affect me, to bring me into different dimensions away from everyday life, and to satisfy my playful mind. (Isabel) It made me cry, feel hopeful, angry, and ended with relief (sic). (Emy)

For others, reading inspires:

Makes me motivate (sic) to do the right and good things. (Connie)

It touched my heart and make me (sic) a believer of love magics (sic). (Ali)

For the participants, reading is more than just an exercise of the mind. It can be an emotionally satisfying activity too. It allows them to experience new worlds and varied emotions and be inspired as well. As Ruddel and Unrau (2013) put it, "rich and rewarding personal experiences with books can change the way a reader feels, acts, and perceives the world" (p.1039). This concurs with Rosenblatt's (2005) argument that students should be taught to read not only to nourish their cognitive needs but more importantly because they ought to understand themselves, their fellow human beings, and humanity. The desire for emotional and psychological satisfaction can also be attributed to the growing complexities in adolescents' emotional makeup.

Since academic readings are predominantly efferent, outside of school the participants explored the aesthetic aspect of reading to satisfy their emotional and psychological needs. One participant summed up how majority of the participants view and feel about the readings done in school. She confessed that she used to be hooked on reading during her elementary years but when she became a teenager, I stop reading. I mean I read but only the ones required in school which are mostly uninteresting. Schools requires (sic) their students to read and read uninteresting textbooks so I read as a form (sic) of requirement to pass not because I love reading. This is in agreement with Park and Kim's (2016) observation that many collegiate students do not enjoy academic reading. It is quite ironic because schools are supposed to have a positive mediating effect (Kozulin, 2003) on students' reading motivation. However, if school-based readings fail to promote reading as an interesting and relevant activity, then there's a need for educators to rethink the literacy activities, practices, and resources that are provided to adolescent learners.

\section{Reading the Past}

It is interesting to note that majority (76\%) of the respondents preferred texts written by foreign authors particularly those from the west. Only $34 \%$ were into stories written by Filipino authors. The list ranged from classics such as Diary of Anne Frank and Great Expectations to contemporary works such as The Notebook, Dare to Fail, Harry Potter, The Fault in Our Stars, Fallen, and Hunger Games.

The students' preference for western authors was consistent with their responses in their first reading experiences; the most interesting stories that they have read; and the books that they wanted to read. Almost all of the participants recalled that the first books their parents bought for them were the Three Little Pigs, The Ugly Duckling, Rapunzel, and Goldilocks. They were introduced to Filipino stories for children such as Juan Tamad (Lazy Juan) only when they went to school. When asked about the books that they plan to read in the future, all except for one chose foreign novels by western authors such as Charlotte Bronte, J.K. Rowlings, Lauren Kate, Suzanne Collins, and Nicholas Sparks.

Ironically, only one Filipino author was popular among the participants - Bob Ong. Filipino teenagers liked the work of this writer because of the humorous writing style and the use of conversational language. And except for the Malaysian writer Billi Lim whose works are written in English, no one knew any other Asian writers.

Valorization of western or British American literature can be attributed to the Filipinos' subscription to the educational system of our western colonizers specifically the Americans. When the colonizers left the Philippines after long years of colonization, they also left a country that was so smitten with their educational system and culture (Doronilla, 1996). Up to this day, Filipinos have not yet recovered from their colonial hangover. The view of dominant literacies holds true in the Philippines as a result of colonization and fascination with the English language. Dominant and subordinate literacies (dela Piedra, 2010) are imposed by social institutions primarily the school. Until now English is the dominant literacy while Filipino and the other local languages are the subordinate literacies. Street (1984) stated that a process called pedagogization of literacy makes the school literacy the norm. Since the norm in most Philippine schools is the valorization of the English language, it is no surprise that there is a prevailing notion among Filipinos that proficiency in English is the mark of a better educated person. English is widely considered as the language of power and the language of economy as well. This is why Filipino parents would not only buy English books for their children but would also enroll them in private schools. They believe that their children would have access to better-quality English instruction in these schools. Most likely, this is also the reason why teenagers such as the participants in this study prefer to read books written by western authors. Besides, it is easy to read English books since they are written using the Roman script which was adopted by the Filipinos from the western colonizers.

Again, it was noticeable that the participants' favorite books were not the ones that were usually read in school which are mainly text books and informational materials. This shows the predominantly efferent stance that schools take in selecting instructional materials. Rosenblatt (2005) warned that taking a predominant efferent stance may result in an artificial relationship with reading.

\section{Reading Heroes}

Many participants shared that their friends were the main reasons why they get to like reading. One male student discovered The Diary of a Whimpy Kid through a friend who was carrying the book. Later, it became a personal favorite because its (sic) like they (sic) were telling my life. Not a few admitted that seeing their friends read gave them the impression that reading is a 'cool' act. Another articulated that she and her friends enjoyed talking about what they have read as it is a way to bond with each other. Peers' influence on 
reading preferences and habits can be attributed to the fact that adolescents tend to spend more of their time with friends and get to value their opinions (Nurmi, 2004).

Furthermore, the participants related that when they were young, their parents, mostly their mother either read to them or bought them books. But as they grew older, family involvement in their literacy activities gradually diminished. According to Wiseman (2011) adolescents already have their own perception of personal and social development which is now more independent and more autonomous. And besides, family involvement is also determined by educational experiences of the parents, economic opportunities, and cultural differences (Green, Walker, Hooevr-Dempsey, \& Sandler, 2007). Apparently, parents with limited education lack the confidence to participate in the literacy development of their children. It is particularly true in the Philippines where the dominant literacy in the secondary and collegiate level is English. It is limiting the involvement of parents with less knowledge in the language. Still, one participant recalled that her father who was a voracious reader infected me with the reading bug and continued to be a major influence in her reading choices.

On the other hand, two participants looked up to their teachers as their reading models. One shared that she was not into reading until a teacher in a literary criticism class in college introduced her to the book, Great Expectations which became a memorable experience that lead to a habit of reading. She recalled how this teacher's eyes would lit up every time she shared about the books that she had read. Another participant's love affair with books was inspired by a Grade 5 teacher who gifted her the book, Dare to Succeed on graduation day. The books that she read from then on were of the same genre as that book. Unfortunately, these two students were the only ones who were inspired to read by their teachers. What the others don't say actually says a lot: either they had teachers who don't read other than what they are supposed to teach or who don't care about their students' literacy growth. In Vygotsky's view of the reciprocity of teaching and learning, emotion is central to both processes (Levykh, 2008). It implies that teachers teach not only because of the knowledge they can share but more than anything else, they also care for their "students' present and future well-being and overall development" (Levykh, p. 92). Later, this should inspire the children to pursue intellectual and emotional development at its highest level. Teachers are recognized as agents of semiotic mediation (Hassan, 1995). Thus they should be capable of designing and implementing a literacy instruction that engage students to read. In the first place, teachers who find reading enjoyable would likely share their enthusiasm with their students. Rudell and Unrau (2013) emphasize that teachers should effect motivational changes and changes in attitude, values, and beliefs towards reading among students.

\section{Online Engagement}

That the participants' reading activities mostly take place in the Internet is no longer surprising. After all, they are millennial learners who are immersed in multimodal learning (Moyer, 2011). One participant would download stories and read every day, saying that it is addicting. She liked online reading be- cause she could read all that she wanted to read. She said that she could not afford to buy printed books and thought that Internet reading is free. Another shared that the Internet became his 'library' where he could read everything he liked wherever he went to and whenever he chose to. He often found reading materials in school uninteresting and 'archaic.' I am educated by the Internet. I don't know but it is easier for me to read in the Internet, he confessed. How this student felt about classroom reading is tantamount to "being victimized of positioning by schools that have devalued literacy activities at which adolescents are literate and competent" (Pitcher et al., 2007, p. 379).

In conclusion, the participants agreed that the interactive nature of e-reading is interesting and engaging. It allows them to experience the text in multiple dimensions. This concurs with the finding of Reoperez (2015) that students were more confident when reading online for they could easily access vocabulary meanings and modify and enrich their background of the topics.

\section{CONCLUSIONS AND IMPLICATIONS}

Results yielded in this study showed that emotional and psychological satisfaction, prosocial goals, prevailing social values, and multimodal learning experiences drive the motivation to read among adolescents. Several implications to literacy instruction can be derived from this. First, it is of paramount importance to strike a balance between efferent and aesthetic reading. The latter will address adolescents' needs for emotional and psychological nourishment. Second, adolescents' voices should be heard in decision making in the literacy instruction. Their text preferences, present concerns, personal and social contexts, and aspirations should be considered for literacy activities to be meaningful, relevant, and engaging. Third, it should be recognized that the shift in modalities and genres in reading brought changes not only in how young people read, but also in the motivation that they bring to the reading act. The fact that they engaged in nonacademic reading showed that they don't abhor reading. But if classrooms persist to provide unreal-world interactions and to ignore adolescents' preferred modes of literacy learning then the feeling of alienation will likewise persist. Lastly, teenagers should be guided to reflect on how their adopted social values could impact reading experiences and literacy growth. While it is true that prevailing social values greatly influence reading motivation, these should not delimit them from exploring different genres, topics, and authors. That the joys of reading could still be experienced in any language must be communicated to learners in a bilingual setting where there is a dominant literacy such as English.

\section{REFERENCES}

Amicucci, A. (2014). "How they really talk" two students' perspectives on digital literacies in the writing classroom.

Journal of Adolescent and Adult Literacy, 57(6), 483-491. doi:10:1002/jaal.274.

Berg, M. (2011). On the cusp of cyberspace: Adolescents' online text use in conversation. Journal of Adolescent and Adult Literacy, 54 (7), 485-493. Doi: 10.1598/JAAL.54.7.2. 
Bozack. A. \& Salvaggio, A.N. (2013). Relational effects of reading motivation and academic achievement among adolescent boys. Reading Psychology, 34, 507-522. Doi:10.1080/02702711.2012.660302.

Brozo, W., Sulkunen, S., Shiel, G., Garbe, C., Pandian, A., \&Valtin, R. (2014). Reading, gender, and engagement (lessons from five PISA countries). Journal of Adolescent and Adult Literacy 57(7), 584-593.

Brown, C., Danvers, K., \& Doran, D. (2016). Student perceptions on using guided reading questions to motivate student reading in the flipped classroom. Accounting Education 25(3), 256-271. http://dx.doi.org/10.1080/09 639284.2016 .1165124$.

Brozo, W., Shiel, G., \& Topping, K. (2007). Engagement in reading: Lessons learned from three PISA countries. Journal of Adult and Adolescent Literacy, 51 (4), 304315. Doi:10.1598/JAAL.51.4.2.

Conradi, K. Jang, B.G., Bryant, C., Craft, A., \& McKenna, M. (2012). Measuring adolescents' attitudes toward reading: A classroom survey. Journal of Adolescent and Adult Literacy 56 (7), 565-576. doi:10.1002/JAAL.183.

Corpus, J., McClintic, M., \& Hayenga, A. (2009). Within-year changes in children's intrinsic and extrinsic motivational orientations: Contextual predictors and academic outcomes. Contemporary Educational Psychology,34, 154-166.

Dela Piedra, M. (2010). Adolescent world and literacy practices on the United States-Mexico border. Journal of Adolescent and Adult Literacy, 53(7), 575-584.

Doronilla, M.L. (1996). Ethnographic study of functional literacy in marginal Philippine communities. US Department of Education.

Gambrell, L.B., Palmer, B.M., Mazzoni, S.A. (1996). Assessing reading motivation. The Reading Teacher, 49(7), 518-533.

Gilbert, J. \& Fister, B. (2011). Reading risk, and reality: College students and reading for pleasure. College and Research Libraries, 474-495.

Gredler, M. (2009). Hiding in plain sight: The stages of mastery/self-regulation in Vygotsky's cultural-historical theory. Educational Psychologist, 44(1), 1-19. DOI: $10.1080 / 00461520802616259$.

Green, C. L. Walker, J.M., Hoover-Dempsey, K.V., \& Sandler, H.M. (2007). Parents' motivations for involvement in children's education: An empirical test of a theoretical model of parental involvement. Journal of Educational Psychology, 99(3), 533-544.

Groenke, S. (2017). "I had no idea he was a reader!" Learning from beginning English teachers' implementation of the adolescent Motivation to Read Profile survey. Journal of Adolescent Adult Literacy, 60(6), 701-704. doi:10.1002/jaal.632.

Guthrie, J.T., \& Wigfield, A. (2000). Engagement and motivation in reading. In M.L. Kamil, P.B. Mosenthal, P.D.

Pearson, \& R. Barr (Eds.), Handbook of reading research, Vol. III. (pp. 403-422). New York, NY: Erlbaum.

Hassan, R. (1996). Speech genre, semiotic mediation and the developmental functions. In C. Cloran, D. Butt \&
G. Williams (Eds.). Ways of saying: ways of meaning. London: Cassell.

Henk, W.A., Marinak, B.A., \& Melnick, S.A. (2012). Measuring the reader self-perceptions of Adolescents: Introducing the RSPS. Journal of Adolescent and Adult Literacy, 56(4), 311- 320. doi:10.1002/JAAL.00144.

Huang, S., Capps, M., Blacklock, J., \& Garza, M. (2014). Reading habits of college students in the United States. Reading Psychology, 35(5), 437- 467. doi:10.1080/0270 2711.2012.739593.

International Reading Association. (2003). Adolescent literacy: A position statement. Retrieved July 2013 from http://www.literacyworldwide.org/docs/.

International Literacy Association. (2017). What's hot in literacy: 2017 report. Retrieved January 2018 from http:www.literacyworldwide.org.

(2018). What's hot in literacy: 2018 report. Retrieved January 2018 from http: www.literacyworldwide.org.

Johnson, D. (2010). Teaching with authors' blogs: Connections, collaboration, creativity. Journal of Adolescent Adult Literacy, 54(3), 172-180. Doi: 10.1598/jaal.54.3.

Judge, P. (2011). Driven to read: Enthusiastic readers in a Japanese high school's extensive reading program. Reading in a Foreign Language, 23(2), pp. 161-186.

Kerr, M.M. \& Frese, K. (2017). Reading to learn or learning to read? Engaging college students in course readings. College Teaching, 65(1), 28-31. http://dx.doi.org/10.10 80/87567555.2016.1222577.

Kim, K.J. (2011). Reading motivation in two languages: An examination of EFL college students in Korea. Springer Science + Business Media, 24, 861-881. Doi: 10.1007/ s11145-010-9229-z.

Kirchhoff, C. (2013). L2 extensive reading and flow: Clarifying the relationship. Reading in a Foreign Language. 25(2), 192-212.

Klauda, L.K. (2009). The role of parents in adolescents' reading motivation and activity. Educational Psychology

Klauda, S.L. \& Guthrie, J. (2014). Comparing relations of motivation, engagement, and achievement among struggling and advanced adolescent readers. Read Writ, 28, 239-269.

Klauda, L.K. \& Wigfield, A. (2012). Relations of perceived parent and friend support for recreational reading with children's reading motivations. Journal of Literacy Research, 44(1), 3-44. doi: 10.1177/1086296XI11341158.

Kozulin, A. (2003). Psychological tools and mediated learning. In A. Kozulin., B.Gindis., V. Ageyev, \& S. Miller (Eds), Vygotsky's Educational Theory in Cultural Context. Cambridge University Press, London.

Levykh, M. (2008). The affective establishment and maintenance of Vygotsky's Zone of Proximal Development. Educational Theory, 58(1), 83-93.

Lone, F.A. (2011). Reading habits of rural and urban college students in the $21^{\text {st }}$ Century. Library Philosophy andPractice E-Journal, 586.

Lau, K.L. (2009). Reading motivation, perception of reading instruction, and reading amount: A comparison of 
junior and secondary students in Hongkong. Journal of Research in Reading, 32, 366-382.

Lau, K. (2016) Within-year changes in Chinese secondary school students' perceived reading instruction and intrinsic reading motivation. Journal of Research in Reading, 39(2), 153-170. doi:10.1111/1467-9817.12035.

Logan, S., Medford, E., \& Hughes, N. (2011). The importance of intrinsic motivation for high and low ability readers' reading comprehension performance. Learning and Individual Differences, 21,124-128. Doi: 10.1016/j. lindif 2010.09.011.

Martin, A.J. (2009). Motivation and engagement across the academic life span. Educational and Psychological Measurement 69(5). 794-824.

Moyer, J. (2011). What does it really mean to 'read' a text? Journal of Adult and Adolescent Literacy, 55 (3), 253256. Doi:10.q002/JAAL.00031.

National Institute for Literacy. (2007). What content-area teachers should know about adolescent literacy. USA: NICHD.

National Endowment for the Arts. (2007). To read or not to read: A question of national consequence. Library of Congress, USA.

Nurmi, J. (2004). Socialization and self-development: Channeling, selection, adjustment, and reflection. In R.M. Lerner \& L. Steinberg (Eds.). Handbook of Adolescent Psychology. Hobokem, NJ: Wiley \& Sons.

OECD. (2010). PISA 2009 results: Learning to learn-student engagement, strategies, and practices, vol. 3. Retrieved From dx.doi.org/10.1787/9789264083943-en.

Pitcher, S., Albright, L., DeLaney, C., Walker, N. Seunarinesingh, K., Headley, K., Mogge, S., \& Ridgeway, V. (2007). Assessing adolescents' motivation to read. Journal of Adult and Adolescent Literacy, 50(5), 378-386.

Reoperez, M.G. (2016). Un-trad me: Exploring Filipino adolescents' views on gender, friendship, and leadership through digital modalities. (2016). Hansraj Jivandas College's Journal on Futuristic Education. 143-154. Gujarat Research Society, Mumbai, India.
Rogoff, B. (1995). Observing sociocultural activity on three plans: Participatory appropriation, guided participation and apprenticeship. In J.V. Werstch, P. Del Rio, and A. Alvarez. (eds.) Sociocultural studies of mind, 139-164. New York, NY: Cambridge University Press.

Rosenblatt, L. (2005). The acid test of for literature teaching. In L. Rosenblatt (Ed). Making meaning with texts, (pp. 62-72). Heinemann. Portsmouth, NH.

Ruddell, B.\& Unrau, N. (2013). Reading as a meaning construction processes: the reader, the text, and the teacher. In R. Ruddell and N. Unrau (Eds). Theoretical models and processes of reading (4th ed.), (pp. 1015-1068). Newark, DE: International Reading Association.

Schaffner, E., Schiefelle, U., \& Ulferts, H. (2013). Reading amount as a mediator of the effects intrinsic reading motivation on reading comprehension. Reading Research Quarterly, 48(4), 369-385.

Street B.V. (1984). Literacy in theory and practice. New York: Cambridge University Press.

Strommen, L.T. \& Mates, B.F. (2004). Learning to love reading: Interviews with older children and teens. Journal of Adolescent and Adult Literacy, 48, 188-200.

Trice, J. \& Wilmes, B. (2011). University reading: How do we turn it on? Administrative Issues Journal: Education, Practice, and Research 1(1), 121-131.

Wiseman, A. (2011). Family involvement for adolescents in a community poetry workshop: Influences of parent roles and life context variables. The School Community Journal, 21 (2), 99-119.

Wolters, C., Barnes, M., Kulesz, P., York, M., \& Francis, D. (2017). Examining a motivational treatment and its impact on adolescents' reading comprehension and fluency. The Journal of Education Research, 110 (1), 98-109. Doi:10. 1080/00220671.2015.1048503.

Vygotsky. L. (1978). Mind in society: The development of higher social processes. M. Cole, V.J., Steiner, V.Scribner, \& E. Souberman (Eds). Harvard University Press. Cambridge, United Kingdom. 